\title{
Evaluation of Nutritional and Physico-Chemical Properties of Several Selected Fruits in Bangladesh
}

\author{
M. Nazmul Haque ${ }^{a}$, Barun Kanti Saha ${ }^{b *}$, M. Rezaul Karima and M. Nurul Huda Bhuiyan ${ }^{\mathrm{b}}$ \\ ${ }^{a}$ Department of Applied Nutrition and Food Technology, Islamic University, Kushtia, and ${ }^{b}$ Institute of Food \\ Science and Technology, BCSIR, Dhaka, Bangladesh.
}

\begin{abstract}
In this study, various parameters on nutritional and physico-chemical characteristics of eight different fruits (five minor and three major fruits), namely melon, guava, papaya, karanda, burmese-grape, velvet apple, wood-apple and pomelo of Bangladesh were analyzed to determine the edible portion of whole fruit, $\mathrm{pH}$, titratable acidity, moisture, total soluble solid, reducing sugar, total sugar, crude fibre, total carbohydrate, total protein, total fat, total energy, vitamin C, ash , sodium, potassium, iron and arsenic content. The largest amount of iron, 5.34 $\mathrm{mg} / 100 \mathrm{~g}$ was observed in Burmese-grape. The pomelo contained the highest amount of potassium, 233.07mg/100g and the lowest amount of sodium, $2.25 \mathrm{mg} / 100 \mathrm{~g}$. The maximum amount of fibre, $6.21 \%$ was found in wood-apple and the richest quantity of vitamin C, $80 \mathrm{mg} / 100 \mathrm{~g}$ was found in guava. In general arsenic was not found in karanda, burmese grape, guava, pomelo, wood-apple, and papaya and only negligible amount of arsenic was revealed in velvet apple, $0.01 \mathrm{mg} / \mathrm{kg}$, followed by melon, $0.005 \mathrm{mg} / \mathrm{kg}$.
\end{abstract}

Key words: Minor and major fruits, Malnutrition, Micronutrient, Bangladesh

\section{Introduction}

The Asian region is rich in diversity of tropical fruit species, particularly in South and Southeast Asia. Fruits are very important for the populations in the region, as sources of supplemental food, nutritionally balanced diets, and help to protect from illness. Some species have specific medicinal uses, while others are used for timber, fuel wood and livestock feed. The South Asian region comprising India, Pakistan, Bangladesh, Nepal, Sri Lanka, Bhutan and the Maldives has a wide range of climatic conditions with the altitude and agro- ecology suited for a wide diversity of tropical fruits. This region is the centre of origin of about 50 species of fruits. About 20 of these are important and are grown in several countries. The major fruits grown in these countries are banana, mango, citrus, pineapple and papaya. Besides these, a large number of minor fruits are also grown in the region (Chandha, 1989).

More than 90 vegetables and 60 fruits are grown in Bangladesh, with great regional variation in the extent of cultivation. May, June and July are specially treated as fruit festival months in Bangladesh when almost all the major and minor fruits are matured and available The most widely cultivated fruits called major fruits are mango, jackfruit, pineapple, banana, litchi, guava, papaya, melon, watermelon, plum. Of the minor fruits i.e., the less cultivated or wild fruits, the following are very common and popular: Black berry (kalo jam), Tamarind (tetul), Palmyra palm (tal), Monkey jack (dewa), Indian olive (jalpai), Carambola (kamranga), Star apple (jamrul), Mangosteen (kaw), Burmese grape (latkan), Velvet apple (bilati gab), Wood apple (kathbel), Indian apple (bel), Custard apple (ata), and Indian Goose berry (amlaki).

Despite substantial improvement in the status of health and nutrition, the rates of malnutrition among children and adults in Bangladesh are still among the highest in the world (Helen Keler and IPHN, 1990) due to eighty percent of population lives below poverty line (BBS, 1993). It has been estimated that at least one third of the people living in developing countries are affected by micronutrient deficiencies (Mason et al., 2001). It is recognized that these deficiencies are more prevalent than protein energy malnutrition (PEM), as the cheapest foods which make up the usual diets of the poor people have the lowest content of available micronutrients. Among the micronutrient malnutrition, there are vitamin A, $\mathrm{C}$ and $\mathrm{B}$ deficiency especially riboflavin deficiency, iron deficiency anemia, iodine deficiency disorders, zinc deficiency, copper deficiency etc. Early in the 1990s, WHO estimated that deficiencies of iron, iodine, and vitamin A influenced the health of 2000 million, 1500 million, and 250 million persons respectively; often these deficiencies overlapped in the population group affected (WHO, 1992) .

\footnotetext{
* Corresponding author: E-mail: bksbcsir@yahoo.com
} 
Fruits are a major source of macronutrients such as fiber and micronutrients such as minerals and vitamins $\mathrm{C}$, thiamin, riboflavin, B-6, niacin, folate, $\mathrm{A}$, and $\mathrm{E}$ and many phytochemicals.

Small amount of micronutrients (minerals and vitamins) are needed for good health along with energy food and protein. Vitamins are vital in the control of body chemical reactions. Vitamin C, a highly effective antioxidant is required for the synthesis of collagen and neurotransmitter, norepinephrine which affects mood. In addition, vitamin $\mathrm{C}$ is required for the synthesis of carnitine that is essential for the transport of fat to mitochondria for conversion to energy (Carr and Frei, 1999). Recent research also suggests that vitamin $C$ is involved in the metabolism of cholesterol to bile acids, which may have implications for blood cholesterol levels and the incidence of gallstones (Simon and Hudes, 2000).

Potassium and sodium in a human body are to regulate the various types of body processes, such as acid-base balance, maintenance of osmotic pressure, nerve conduction, muscle contraction and control of heart beat (Deb, 1998).

Fruit rich in fibre has many health benefits. It reduces the risk of a number of bowel problems - constipation, haemorrhoids (piles), diverticular disease and cancer of the colon or large bowel. In addition, soluble fibre helps to stabilise blood sugar levels and also helps to lower blood cholesterol levels, which is important for reducing the risk of heart disease. Furthermore the feeling of fullness which fibre produces can help people who are trying to lose weight to control their appetite. Ideally, adults should aim for an intake of around 18 grams a day, or even a little more Bangladeshi diet is grossly inadequate in energy, protein and micro nutrients. Cereals, largely rice, are the main food in Bangladesh. Nearly two-thirds of the daily diet consists of rice, some vegetables, a little amount of pulses and small quantities of fish if and when available. Milk, milk products and meat are consumed only occasionally and in very small amounts. Fruit

consumption is seasonal and includes mainly papaya and banana which are cultivated round the year (Jahan and Hossain, 1998). With an average national per capita consumption of $23 \mathrm{~g}$ of leafy vegetables, $89 \mathrm{~g}$ of non-leafy vegetables and $14 \mathrm{~g}$ of fruit, the average Bangladeshi eats a total of $126 \mathrm{~g}$ of fruit and vegetables daily. This is far below the minimum daily consumption of $400 \mathrm{~g}$ of vegetables and fruit recommended by FAO and the World Health Organization (WHO, 2003). Inadequate consumption of fruits and vegetables is estimated to cause about 31 percent of ischaemic heart disease and 11 percent of strokes worldwide (WHO, 2002). Overall, it is estimated that up to 2.7 million lives could be saved every year with a sufficient increase in fruit and vegetable consumption. Although there are a large num- bers of fruits in Bangladesh, but food composition table for all fruits is not available that is necessary for national nutritional planning as well as monitoring of an individuals nutrient intake. For that reason, several fruits are being analyzed to develop a new and updated food composition table and encourage the people for taking more fruits that would prevent the micronutrient malnutrition of the people in Bangladesh.

\section{Materials and Methods}

This experiment was carried out at Institute of Food Science and Technology, BCSIR, Dhaka. Eight types of fruits were analyzed in this study. The selected fruits were collected from different local markets in Dhaka city during the period from June to August 2007. Collected samples were fresh, matured, well shaped, and free from insect's bites and other organoleptic deterioration. The freshly collected sample was washed with deionized water to eliminate visible dirt and removed the water quickly with a blotting paper. Then the sample was cut into small pieces, homogenized and accurate amount was weighed as required for different analysis and the analytical data were present on a wet weight basis.

The edible portion of whole fruit was determined by subtracting the weight of inedible parts (e.g., skin and seed) of fruits from the weight of whole fruits. The $\mathrm{pH}$ was determined with a digital pH meter (Ibrahim, 2002) and titratable acidity was estimated with the visual acid-base method (Ranganna, 1986). Moisture content was determined by digital moisture analyzer. The total soluble solid (TSS) was determined with a hand refractometer (Gofur et al., 1998). Reducing sugar and total sugar were determined by Lane and Eynon method (Ranganna, 1986). Crude fiber was determined by AOAC (1980). The estimation of total protein was made by Kjeldahl method and the total fat content of sample was determined by the standard AOAC method (AOAC, 1990). The content of total carbohydrate was determined by the following equation:

Carbohydrate $(\%)=100-\{$ Moisture $(\%)+$ Protein $(\%)+$ Fat (\%) + Ash (\%)\}

Vitamin C was determined titrimetrically using 2, 6-dichliorophenolindophenol (Bessy and King, 1933; Mahadevan and Sridhar, 1982). Ash was determined by heating sample at $600^{\circ} \mathrm{C}$ for six hours or until a constant weight was reached.

Sodium and potassium contents were determined by Flame photometric method and iron content was determined by spectrophotometrically. Arsenic content of fruit was determined using analytical test kit method. The gross food energy was estimated( Edeoga et al., 2003; Osborn and Voogt, 
1978), using the equation:

$\mathrm{FE}=(\% \mathrm{CHO} \times 4)+(\% \mathrm{CF} \times 9)+(\% \mathrm{CP} \times 4)$

Where FE = Food Energy in Kcal /g, CF = Crude Fat, CP = Crude Protein.

\section{Results and Discussion}

The composition of fruits may vary from one continent to another, one country to another in the same continent and in the same country, and also may occur region to region. This variation may be due to change of climatic condition, nature of soil and sometimes rainfall. The results of the investigation on nutritional and physico-chemical parameters of three major and five minor fruits are given in the table I and table II respectively.

The edible portion of eight varieties of the selected fruits was determined and the results showed that the highest amount of edible portion among major fruits was observed in guava, 93.13\% and among the minor fruits the highest edible portion was found in Karanda, 89.56\%. Edible portion of guava may be $100 \%$ because many people consume the whole portion (pericarp and seed) of guava. Between the two groups the lowest amount of edible portion was found in pomelo,
41.40\% due to thick skin (outer epicarp). Most fruits and vegetables are composed of $70 \%$ to $90 \%$ water (Ranganna, 1986). The moisture content of eight different fruits ranged between $70.21 \%$ and $95.39 \%$. Among the fruits analyzed, melon contains the highest amount of water around $95.39 \%$ and the minimum amount of moisture was found in burmese grape, $70.21 \%$. In this study, it was found that the ripe fruits contain more amount of water than green fruits. Moisture content of different fruits depends on some factors including rainfall, soil water and type of soil. Soil moisture supply mainly depends on rainfall (Webster and Wilson, 1966).

The $\mathrm{pH}$ among the both groups varied from 2.4 to 4.6. The lowest $\mathrm{pH}$ (2.4 ) was found in burmese grape and the highest amount of titratable acidity was seen in karanda, 3.76\%. On the other hand, the highest $\mathrm{pH}$ (4.6) was observed in velvet apple and the lowest amount of titratable acidity was found in papaya, $0.2 \%$. Ceggara (1964) found that the $\mathrm{pH}$ range of ripe fruits was 4.5 to 5.35 .

The total soluble solids (TSS) among eight different fruits of major and minor were $2 \%$ to $16 \%$. The highest amount of TSS was found in wood apple, $16 \%$ and the lowest in melon, $2 \%$. Generally higher TSS indicates more sugar in the pulp. The more ripe the fruits the more amount of sugar in fruits.

Table I. Nutritional and physicochemical parameters of major fruits. (Result expressed as per 100g of edible portion)

\begin{tabular}{|c|c|c|c|}
\hline & \multicolumn{3}{|c|}{ Major fruits } \\
\hline Samples & Melon (Cucumis melo) & Guava (Psidium guajava) & Papaya (Carica papaya \\
\hline Local name & Bangi & Payara & Pape \\
\hline Maturity status & Ripe & Matured & Ripe \\
\hline $\begin{array}{lc}\text { Analytical parameters } \\
\text { Edible portion } & \text { (g) } \\
\text { pH } & \\
\text { Titratable acidity } & \text { (g) } \\
\text { Moisture } & (\mathrm{g}) \\
\text { TSS } & (\mathrm{g}) \\
\text { Reducing sugar } & (\mathrm{g}) \\
\text { Total sugar } & (\mathrm{g}) \\
\text { Crude fibre } & (\mathrm{g}) \\
\text { Carbohydrate } & (\mathrm{g}) \\
\text { Protein } & (\mathrm{g}) \\
\text { Fat } & (\mathrm{g}) \\
\text { Energy } & (\mathrm{Kcal}) \\
\text { Vitamin C } & (\mathrm{mg}) \\
\text { Ash } & (\mathrm{g}) \\
\text { Sodium } & (\mathrm{mg}) \\
\text { Potassium } & (\mathrm{mg}) \\
\text { Iron } & (\mathrm{mg}) \\
\text { Arsenic } & (\mathrm{mg} / \mathrm{Kg}) \\
\end{array}$ & $\begin{array}{c}69.4 \\
4.1 \\
0.32 \\
95.39 \\
2.0 \\
1.54 \\
1.9 \\
1.66 \\
3.89 \\
0.45 \\
0.0084 \\
17.87 \\
33.0 \\
0.268 \\
2.62 \\
0.42 \\
0.45 \\
0.005 \\
\end{array}$ & $\begin{array}{c}93.13 \\
3.7 \\
0.3 \\
83.22 \\
6.0 \\
3.35 \\
3.68 \\
3.97 \\
15.52 \\
0.89 \\
0.023 \\
67.49 \\
80.0 \\
0.341 \\
2.58 \\
3.7 \\
0.61 \\
0.00 \\
\end{array}$ & $\begin{array}{c}89.35 \\
4.3 \\
0.2 \\
86.85 \\
11.75 \\
4.38 \\
5.56 \\
4.51 \\
10.93 \\
1.9 \\
0.02 \\
52.79 \\
51.0 \\
0.292 \\
11.71 \\
0.22 \\
0.6 \\
0.00 \\
\end{array}$ \\
\hline
\end{tabular}

Each value represents the average from three replications 
The highest amount of reducing sugar and total sugar were observed in burmese-grape, $5.50 \%$ and $11.54 \%$ respectively. The minimum amount of reducing sugar $\&$ total sugar were found in melon, $1.54 \%$ and $1.90 \%$ respectively. According to Norman (1976), the sugar content of fresh fruits ranges between $2 \%$ and $30 \%$. This range is similar to the present study. Carbohydrate of fruit is less concentrated than cereals because of their high water content. In the study, total carbohydrate present in fruits ranges between $3.89 \%$ and $28.25 \%$. The highest amount of carbohydrate was present in burmesegrape $28.25 \%$ and the lowest amount of carbohydrate was present in melon $3.89 \%$. Fruits rich in carbohydrate provides high amount of energy. Burmese- grape showed the highest amount of energy, $122.11 \mathrm{kcal} / 100 \mathrm{~g}$ due to its high carbohydrate content. Melon had the lowest energy content, 17.87 $\mathrm{kcal} / 100 \mathrm{~g}$ because of its lower carbohydrate content. Dietary fibre, the important constituent of fruit ranges from $1.66 \%$ to $6.21 \%$. Wood-apple contains the maximum amount of fibre $6.21 \%$ and the minimum amount was observed in melon, $1.66 \%$.

Fruits contain small amount of protein. In general, protein content of different fruits is not greater than $3.5 \%$ in accor dance with Norman (1976). In this study, it was found that protein content of different fruits ranges between $0.4 \%$ and $3.17 \%$. This range supports the reference value. According to Norman (1976), usually fat content of different fruits is not greater than $1 \%$. In this study, it was seen that the fat content of different fruits ranged between $0.0084 \%$ and $1.27 \%$.

The highest amount of fat was found in karanda, $1.27 \%$ and the lowest amount was found in melon, $0.0084 \%$.

In this study, it was observed that guava (80mg/100g), pomelo $(53.2 \mathrm{mg} / 100 \mathrm{~g})$ and papaya $(51 \mathrm{mg} / 100 \mathrm{~g})$ contained highamount of vitamin C. The maximum amount of vitamin C was found in guava, $80 \mathrm{mg} / 100 \mathrm{~g}$ and the lowest amount was present in karanda, $10.5 \mathrm{mg} / 100 \mathrm{~g}$. According to the Nutrition Expert Committee (ICMR, India, 1981), the daily requirement of vitamin $\mathrm{C}$ for adult is $40 \mathrm{mg}$ but the guava contains $80 \mathrm{mg} / 100 \mathrm{~g}$ of vitamin C. So daily $50 \mathrm{~g}$ of guava intake in tropical season can eradicate the scurvy disease. The amount of total ash (mineral) present in selected fruits ranges between $0.053 \%$ and $0.902 \%$. Wood apple contains the highest amount of ash, $0.902 \%$ and burmese- grape con tains the lowest amount of ash, $0.053 \%$. Gardner et.al.

Table II. Nutritional and physicochemical parameters of minor fruits. (Result expressed as per 100g of edible portion)

\begin{tabular}{|c|c|c|c|c|c|}
\hline & \multicolumn{5}{|c|}{ Minor fruits } \\
\hline Samples & $\begin{array}{l}\text { Karanda } \\
\text { (Carissa carandas) }\end{array}$ & $\begin{array}{l}\text { Burmese-grape } \\
\text { (Baccaurea } \\
\text { ramiflora) }\end{array}$ & $\begin{array}{l}\text { Velvet apple } \\
\text { (Diospyros } \\
\text { blancoi) }\end{array}$ & $\begin{array}{l}\text { Wood-apple } \\
\text { (Feronia } \\
\text { limonia) }\end{array}$ & $\begin{array}{l}\text { Pomelo } \\
\text { (Citrus } \\
\text { maxima) }\end{array}$ \\
\hline Local name & Karamcha & Latcon & Bilati gab & Kadbel & Jambura \\
\hline Maturity status & Matured & Ripe & Ripe & Matured & Ripe \\
\hline $\begin{array}{lc}\text { Analytical Parameters } \\
\text { Edible portion } & \text { (g) } \\
\text { pH } & \\
\text { Titratable acidity } & (\mathrm{g}) \\
\text { Moisture } & (\mathrm{g}) \\
\text { TSS } & (\mathrm{g}) \\
\text { Reducing sugar } & (\mathrm{g}) \\
\text { Total sugar } & (\mathrm{g}) \\
\text { Crude fibre } & (\mathrm{g}) \\
\text { Carbohydrate } & (\mathrm{g}) \\
\text { Protein } & (\mathrm{g}) \\
\text { Fat } & (\mathrm{g}) \\
\text { Energy } & (\mathrm{Kcal}) \\
\text { Vitamin C } & (\mathrm{mg}) \\
\text { Ash } & (\mathrm{g}) \\
\text { Sodium } & (\mathrm{mg}) \\
\text { Potassium } & (\mathrm{mg}) \\
\text { Iron } & (\mathrm{mg}) \\
\text { Arsenic } & (\mathrm{mg} / \mathrm{Kg})\end{array}$ & $\begin{array}{c}89.56 \\
2.5 \\
3.76 \\
85.49 \\
7.0 \\
2.36 \\
2.63 \\
2.79 \\
12.38 \\
0.4 \\
1.27 \\
64.2 \\
10.5 \\
0.458 \\
3.66 \\
5.27 \\
2.57 \\
0.0\end{array}$ & $\begin{array}{c}46.01 \\
2.4 \\
1.4 \\
70.21 \\
12.25 \\
5.5 \\
11.54 \\
4.72 \\
28.25 \\
1.44 \\
0.042 \\
122.11 \\
13.4 \\
0.053 \\
5.0 \\
0.5 \\
5.34 \\
0.0\end{array}$ & $\begin{array}{c}53.64 \\
4.6 \\
0.0864 \\
82.17 \\
13.2 \\
2.8 \\
4.04 \\
3.64 \\
16.52 \\
0.74 \\
0.01 \\
70.85 \\
18.6 \\
0.56 \\
4.4 \\
18.9 \\
2.74 \\
0.01\end{array}$ & $\begin{array}{c}56.34 \\
3.1 \\
4.51 \\
77.99 \\
16.0 \\
2.88 \\
11.4 \\
6.21 \\
17.9 \\
3.17 \\
0.037 \\
86.73 \\
16.4 \\
0.902 \\
6.0 \\
15.33 \\
1.48 \\
0.0\end{array}$ & $\begin{array}{c}41.4 \\
3.5 \\
1.02 \\
90.23 \\
7.0 \\
1.58 \\
3.76 \\
3.51 \\
8.9 \\
0.46 \\
0.028 \\
38.63 \\
53.2 \\
0.376 \\
2.25 \\
233.07 \\
0.2 \\
0.0\end{array}$ \\
\hline
\end{tabular}

Each value represents the average from three replications 
(1939) observed that the total content of mineral salt as ash in fruits varied from $0.2 \%$ to1.5\%. This range is closer to the present study except burmese- grape, $0.053 \%$. Literature reported that fruits contain negligible amount of sodium (Krause and Mahan, 1984). In the present study, it was observed that sodium present in different fruits ranges between $2.25 \mathrm{mg}$ and $11.71 \mathrm{mg} / 100 \mathrm{~g}$ of edible portion. The highest amount of sodium was found in papaya, $11.71 \mathrm{mg} / 100 \mathrm{~g}$ and the lowest amount was in pomelo, 2.25 $\mathrm{mg} / 100 \mathrm{~g}$. Sodium variability of fruits sometimes relies on soil sodium. Black soil contains fair amount of sodium. Potassium is plentiful in fruits (Bennion and Hughes, 1975).

In the present study, the highest quantity of potassium was observed in pomelo, $233.07 \mathrm{mg} / 100 \mathrm{~g}$ whereas papaya contains the lowest amount of potassium, $0.22 \mathrm{mg} / 100 \mathrm{~g}$. The daily recommended intake of sodium and potassium are 920mg to $2300 \mathrm{mg}$ and $1950 \mathrm{mg}$ to $5460 \mathrm{mg}$ respectively for adults (I.C.M.R, 1981). Iron content was found in higher in the burmese- grape, $5.34 \mathrm{mg} / 100 \mathrm{~g}$ and lower in pomelo, 0.2 $\mathrm{mg} / 100 \mathrm{~g}$. Iron present in fruits analyzed ranges between $0.2 \mathrm{mg}$ and $5.34 \mathrm{mg} / 100 \mathrm{~g}$. This result agrees with Gopalan (1993). The daily recommended intake of iron is $7 \mathrm{mg}$ for adult male and $12 \mathrm{mg}$ to $16 \mathrm{mg}$ for adult female. In this study, arsenic was found only in velvet apple, $0.01 \mathrm{mg} / \mathrm{kg}$ and melon, $0.005 \mathrm{mg} / \mathrm{kg}$. Arsenic was not found in karanda, burmese grape, guava, pomelo, wood-apple and papaya. The maximum allowable limit of consumption of arsenic through food by a person is $0.2 \mathrm{mg} / \mathrm{kg}$ per day .

\section{Conclusion}

Fruits are rich sources of fibre, vitamin C and A as well as many important minerals. Among the fruits analyzed, wood -apple contains the maximum amount of fibre. Guava contains the highest amount of vitamin C. Only 50g guava can meet the daily requirement of vitamin $\mathrm{C}$. The cheapest fruit in Bangladesh is pomelo which contains the highest amount of potassium and good source of vitamin C. Burmese-grape contains the largest amount of iron and most fruits are free from arsenic and poor sources of fat. So we can consume fruits more and more without solicitude. Although local fruits contain ample amount of micronutrients, Bangladeshi people have a tendency to purchase the high cost foreign fruits due to ignorance and unavailability of food composition table of fruits. This study will help the people to measure nutrient content and fulfil the daily requirement by cheap and local food items. If we enhance the regular intake of minor fruits along with major fruits, then it is possible to alleviate prevailing micronutrient deficiency problem from Bangladesh.

\section{Acknowledgement}

The authors are grateful to Dr. K.M. Formuzul Haque, Director in-Charge, and Mr. Ekramul Haque, S. S. O, IFST, BCSIR, Dhaka for providing laboratory facilities to carry out the research work. The authors are indebted to Bably Sabina Azhar, Chairman, Applied Nutrition and Food Technology Department, Islamic University, Kushtia for her cordial cooperation.

\section{References}

AOAC (Association of Official Analytical Chemists), Official Methods of Analysis (15th ed.), AOAC inc. Artington Virginia , U.S.A., 1990.P-1094.

AOAC (Association of Official Analytical Chemists),1980. Official Methods of Analysis, Centennial edition 1884-1984, 14th edition, Virginia, U.S.A.

BBS, (1993) Statistical Pocket Book Bangladesh, Bangladesh Bureau of Statistics, Dhaka, Bangladesh.

Bennion M. and Hughes O. (1975) Introductory Foods, 6th edition, Co 11ier-Macmi 11 and Co. Limited. London..

Bessey O. A . and King C. G., (1933) The distribution of vitamin $C$ in plant and animal tissues and its determination. J. Biol. Chem.103: 687-698.

Carr A. C. and Frei B. (1999) Toward a new recommended dietary allowance for vitamin $\mathrm{C}$ based on antioxidant and health effects in humans. Am J Clin Nutr. 69(6):1086-1107.

Cegrra J. R. (1964) Estudios comparative de algunos indices quimicosy fisicos impoortances en variedades de mangos injertados. Fac. De. Agronomia. Univ. Central de Venezuela. .

Chadha K. L. (1989) Current situation and future prospects of production of minor fruits in the Asia-Pacific region. Regional Expert Consultation on Fruits held at Bangkok, Thailand from 13-16 June .

Deb A. C. (1998) Fundamentals of biochemistry, Seventh edition (Thoroughly revised \& updated), New Central Book Agency (P) Ltd., 8/1, Chintamoni Das Lane, Calcutta 700009 (India), P-415-418. 
Edeoga H. O., Okwu D. E. and Mbaebie B. O. (2003) Minerals and nutritive value of some Nigerian medicinal plants. Journal of Medicinal and Aromatic Plant Science. 25: 1010-1015.

Gardner V. R., Bradford F. C. and Hooker H. D. (1939) The fundamentals of fruit production. Mc Graw-Hill, New York, .P-159-172.

Gofur M. A., Shafiq M. Z., Helali M. O. H., Ibrahim M. Rahama M. M. N. and Hakim M. A. (1998) Effect of application of plant hormone on the control of fruit drop, yield and quality characteristics of mango (Mangifera indica L.) Bangladesh J.Sci. Ind. Res, XXI (III) :163-171.

Gopalan C, Rama S. B. V. and Balasubra S. C. (1993) Nutritive Value of Indian Foods, 2nd edition, Indian Council of Medical Research, Hyderabad. .

Helen Keller Worldwide and Institute of Public Health Nutrition (IPHN). Progress in Bangladesh towards the goals of the 1990 World Summit for Children.Nutritional Surveillance Bulletin 2001 Apr; 3: 1-4.HKI, Dhaka.

I.C.M.R. (1981) Nutrition Advisory Committee, Recommended daily allowances of nutrients and balanced diets. Indian Council of Medical Research, New Delhi.

Ibrahim M. (2002) Application of Plant Hormone on the Control of Anthracnose Disease, Yield and Quality Characteristics of Mango. Ph.D. Thesis, Institute of Biological Sciences, Rajshahi University, Bangladesh, . P-181.

Jahan K. and Hossain M. (1998) Nature and extent of malnutrition in Bangladesh, Bangladesh National Nutrition Survey, 1995-1998. Dhaka, Institute of Nutrition and Food Science, Dhaka University, Bangladesh. .

Krause and Mahan (1984) Food, Nutrition and Diet therapy, 7th edition, W.D. Saunders company, Philadelphia. U.S.A.

Mahadevan A. and . Sridhar R (1982) Methods in physicological Plant pathology, 2nd Ed., Shivakmi Publication, Madras, India, P-171.
Mason J. B., Lotfi M., Dalmiy N., Sethuraman K. and Deitchler M., With Geibel S., Gillenwate K., Gilman A., Maso K. and Mock N. ( 2000) The Micronutrient Report: Current Progress in the Control of Vitamin A, Iodine, and Iron Deficiencies. Micronutrient Initiative/International Development Research Center, Ottawa, Canada. ISBN 1-894217-18-7. 2001. Med., 160(7): 931-936.

Norman N. (1976) Potter, Food science, 2nd edition, The Avi publishing company, INC-Westport, Connecticut.

Osborn, D. R. and Voogt, Calculation of Calorific Value. In: The Analysis Of nutrients in Foods. A c a d e m i c Press, New York, 1978. P-239-240.

Ranganna S. (1986) Handbook of Analysis and Quality Control for Fruit and Vegetable Products, Tata McGraw-Hill Publishing Company Lt. New Delhi. P12-123..

Simon J.A, Hudes E. S. Serum ascorbic acid and gallbladder disease prevalence among US adults: The Third National Health and Nutrition Examination Survey (NHANES III). Arch Intern

Webster C. C. and Wilson P. N. (1966) Agriculture in the tropics, 1st edition, Longans green and Co.Ltd. London.

WHO. (2003) Diet, nutrition and the prevention of chronic diseases. Report of a joint FAO/WHO. Expert Consultation. WHO Technical Report Series 916. Geneva. World Health Organization.

WHO. (2002.) World Health Report. Reducing risks, promoting healthy life. Geneva, World Health Organization.

World Health Organization, (1992) unpublished document A45/17). National strategies for overcoming micronutrient malnutrition, Geneva,

Received : November 11, 2008;

Accepted : January 18, 2009 